\title{
Article
}

\section{From Ethnic to Class: Evolution of Korean Entrepreneurship in Argentina}

\author{
Kim, Jihye \\ Available at http://clok.uclan.ac.uk/36264/ \\ Kim, Jihye ORCID: 0000-0002-4254-7114 (2021) From Ethnic to Class: \\ Evolution of Korean Entrepreneurship in Argentina. Korean Studies Journal, \\ 45. pp. 36-61. ISSN 0145-840X
}

It is advisable to refer to the publisher's version if you intend to cite from the work.

For more information about UCLan's research in this area go to

http://www.uclan.ac.uk/researchgroups/ and search for <name of research Group>.

For information about Research generally at UCLan please go to

http://www.uclan.ac.uk/research/

All outputs in CLoK are protected by Intellectual Property Rights law, including Copyright law. Copyright, IPR and Moral Rights for the works on this site are retained by the individual authors and/or other copyright owners. Terms and conditions for use of this material are defined in the policies page.

\section{CLoK}

Central Lancashire online Knowledge www.clok.uclan.ac.uk

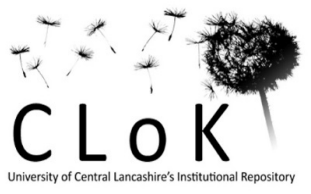




\section{PROJECT MUSE}

From Ethnic to Class: The Evolution of Korean

Entrepreneurship in Argentina

Jihye Kim

Korean Studies, Volume 45, 2021, pp. 36-61 (Article)

Published by University of Hawai'i Press

DOI: https://doi.org/10.1353/ks.2021.0003

$\Rightarrow$ For additional information about this article https://muse.jhu.edu/article/800128 


\title{
From Ethnic to Class: The Evolution of Korean Entrepreneurship in Argentina
}

\author{
Jihye Kim
}

Since the beginning of Korean migration to Argentina in the 1960s, ethnic Koreans in Argentina have been intensively involved in the garment industry. Based on archival and documentary research, along with ethnographic research conducted in Argentina, this study examines what kinds of resources Korean immigrants have relied upon to start up and expand their businesses and how these resources have changed over time. The study reveals that in the development of their garment businesses, Korean entrepreneurs have strategically tapped into ethnic networks and resources to achieve economic viability, financial support, and eventual upward mobility within the Argentine garment industry. Yet the relative importance of these resources to Korean entrepreneurs and their level of dependence on them vary according to settlement stages and circumstances. Findings further suggest that whereas most Koreans have remained closely tied to one particular economic sector, ethnic resources should not be considered an absolute condition for the establishment and development of Korean garment businesses, but rather one of the available resources that facilitates this process, in most cases.

Keywords: ethnic business, Koreans in Argentina, garment industry, ethnic and class resources 


\section{Introduction}

"The fate of an immigrant depends on the people waiting for them at the airport when they arrive in Argentina." I frequently heard this dictum in my interviews with Korean immigrants in Argentina. It demonstrates the importance of ethnic networks and of receiving help from earlier immigrants in the settlement stage. As Korean immigrants to Argentina did not speak the local language and faced discrimination, disadvantages, and difficulties in the host society, they depended heavily on information shared by other Korean immigrants to resolve basic matters, such as renting a house, sharing business/job opportunities, or getting training. In previous studies (Light, 1984; Light and Gold, 2000) collaboration among immigrants was considered crucial to immigrant survival as well as business development, and immigrants relied on ethnic ties and solidarity and cooperated to form communities, open businesses, and overcome obstacles. In this way, "ethnic resources" were created and used among members of the same ethnic group and seen as a vital advantage for immigrants in developing their businesses and in providing them with employment opportunities (Light and Gold, 2000).

In order to understand why immigrants have a high rate of selfemployment in many Western countries in North America and Europe, a significant number of case studies have been conducted and many theories and concepts have been developed, particularly in the United States and Europe. For instance, Koreans in the United States have been heavily concentrated in small businesses, such as liquor stores, grocery stores, nail care, and laundry (Min, 1996; Yoon, 1997). A high proportion of Koreans in Australia run restaurants, cafés, hair salons, and cleaning companies, showing the highest rate of self-employment among ethnic groups and double that of native Australians, according to previous research on immigrant businesses in Australia (Collins, 2008). Korean immigrants in Argentina have not been the exception in terms of this high selfemployment rate. Since the 1960s, when Koreans first began migrating to Argentina, they have focused on the garment industry (Kim, 2020). At first acting as lowly subcontractors in garment manufacturing, starting in the late 1960s, they built their businesses over time (Kim, 2020), by the mid1980s running both production and distribution operations, becoming leaders in the mid-range garment market, and branching out from Buenos Aires, the country's capital, to the rest of the country (Lee, 1992:246-247). Even today an estimated $80 \%$ of the 20,000 ethnic Koreans in Argentina are engaged in the garment industry (Kim, 2020). Although there are 
similarities between Korean entrepreneurs in Argentina and self-employed immigrants elsewhere, this longstanding and enduring affinity with the garment industry has become a distinguishing characteristic of Koreans in Argentina.

In view of the high concentration of Korean Argentines in a specific sector, this research initially approached the problem with a general hypothesis and a singular set of explanatory factors-ethnic resources and networks for their business preparation and operation-thus aiming to empirically explore ethnic resources that Korean immigrant entrepreneurs have utilized to achieve economic viability, financial support, and eventual upward mobility within the Argentine society. However, although Korean immigrants have been continuously involved in the garment industry, their businesses in Argentina today have transformed into something strikingly different from those that were started in the initial stages of Korean immigration to that country, in terms of business scale, business type, management styles, and other related issues. In this context, it is crucial to pay particular attention to how the ethnic resources and networks Korean entrepreneurs have tapped into for their business set-up and operation have varied over time. Thus, in this research I shed light on (1) the types of ethnic resources that Korean immigrants have made use of in their business development in the Argentine garment industry; (2) the ways in which and the reasons why the importance of those ethnic resources has changed over time; and (3) the relationships between ethnic resources and the ethnic business, in terms of the high concentration of Korean Argentines in a specific sector.

In Argentina, I conducted extensive ethnographic field research based on interviews and participant observation, which greatly helped me in incorporating into this study the voices of stakeholders speaking about their own everyday issues and experiences. Applying ethnographic methods, I paid close attention to the specific issues, resources, and factors that the interviewees themselves seemed to consider crucial for their business development. Using my previous connections with the Korean community, I approached interviewees through a snowball (chainreferral) sampling technique, whereby existing study participants would help me recruit further participants from among their acquaintances. In total, 77 interviews were conducted in Korean or Spanish. The main participants were active Korean entrepreneurs, but I intentionally included retired entrepreneurs, employees, and members of other ethnic groups, all of them with different trajectories within the garment industry. The interviews usually took one to two hours, though sometimes stretching to 
three hours or even longer. I primarily relied on biographical interviews that encouraged the participants to tell their life stories freely; as they talked, I endeavored to guide them towards the research questions.

With my interviewees' permission, I visited several of their wholesale and retail garment shops, factories, and sewing and knitting workshops to conduct on-site observation. I also engaged in participant observation mainly at wholesale/retail garment shops, helping them sell clothing and interacting with their clients and other people related with their businesses. Along with my interview data, my field notes, kept daily using all the details arising from my observations, informal conversations, questions, and reflections, were one of the foremost outcomes of my field research, helping me interpret and analyze my field data. I applied additional research methods, such as archival research at the archives of the Korean Times newspaper in Buenos Aires and an examination of online resources related to Korean associations and garment companies; those sources were helpful to understand the development of Korean garment businesses, identify the main resources that they have relied on, and compare the differences between the conditions, factors, and variables of the past and the present.

\section{Immigrant Entrepreneurship and Ethnic Resources}

For decades, business ownership has been a preferred point of entry for many immigrant groups in the numerous immigrant-receiving countries in North America and Europe (Waldinger et al., 1990). Scholars from various disciplines have endeavored to explain this prevalent and persistent preference for immigrant self-employment, developing theoretical frames such as "labour market disadvantages," "middleman minorities," "ethnic enclaves," and "class and ethnic resources." For instance, some scholars (Waldinger et al., 1990; Light and Bonacich, 1991; Light and Rosenstein, 1995; Barrett et al., 1996; Light and Gold, 2000) attribute the high rate of immigrants in self-employment to the labor market disadvantages they face in the host countries. These disadvantages include racial discrimination, language barriers, unfamiliarity with the host culture and laws/regulations, and limited job opportunities. "Middleman minority" is the term used for a minority group that plays an intermediary role, linking dominant and dominated groups in the running of their business (Bonacich, 1973; Turner and Bonacich, 1980; Zenner, 1991). In particular, many researchers (Light and Bonacich, 1991; Min, 1996; Yoon, 1997; Min and Kolodny, 1999) have indicated that Korean entrepreneurs in the United States play the role of 
minority middlemen because they are caught in vulnerable positions between white providers and low-income black customers. "Ethnic enclave" refers to geographic areas with high ethnic concentration of ethnically close communities, which helps new immigrants with opportunities and information through networking (Portes, 1987; Zhou, 1995; Portes and Shafer, 2007; Zhou, 2009). In this same regard, "ethnic resources" are created and utilized among members of the same ethnic group, so they are seen as a crucial advantage for immigrants to develop their businesses. However, some scholars also claim the importance of "class resources," such as individual capacity and class background, in the formation and operation of ethnic enterprise (Light, 1984; Light and Bonacich, 1991; Yoon, 1991; Light and Rosenstein, 1995; Yoon, 1997; Light and Gold, 2000).

The main theories on immigrant business mentioned above have significantly influenced the ways in which problems and issues involving immigrant entrepreneurs are framed and have been extensively applied to other case studies in Western countries. More recent theories, such as those of structural opportunity and mixed embeddedness, recognize the crucial significance of immigrant social capital and ethnic resources in the entry into and operation of immigrant enterprises, but also places them together with the wider social, economic, and political contexts of the host country as explanatory factors. While the structural opportunity approach focuses on market positions and dimensions (Waldinger, 1986, 1989; Waldinger et al., 1990), the more recent construct of mixed embeddedness advocates for a more comprehensive approach that also takes into account laws, regulations, institutions, and governmental practices, recognizing their vital influence on how markets operate (Kloosterman et al., 1999; Kloosterman and Rath, 2001; Rath, 2002; Kloosterman, 2010).

Light and Gold's distinction between class and ethnic resources provides valuable insight into understanding the contribution of ethnic and class resources to Korean immigrant entrepreneurship in Argentina, in particular, how the relative significance of ethnic and class resources changes over the course of business development. On finding that some contemporary immigrant groups, for instance Koreans in the United States, are more reliant on class than ethnic resources for business development, in their book on ethnic economies, Light and Gold (2000) make a distinction between "class" and "ethnic" resources. Class resources derive primarily from "private property and wealth," as well as from "values, attitudes, knowledge, and skills transmitted in the course of socialization from one generation to another" (Light, 1984:201-202; Light 
and Gold, 2000:84). Ethnic resources, on the other hand, include "identifiable skills, organizational techniques, reactive solidarity, sojourning orientation, and other characteristics based in group tradition and experience" (Light, 1984:201; Light and Gold, 2000:105). A focus on ethnic resources leads to a view of ethnic entrepreneurship as collectivistic, while an emphasis on class resources leads to a more individualistic interpretation (Yoon, 1991).

Although previous research conducted on immigrant businesses in the United States sparked discussion on the distinction between ethnic and class resources utilized by Korean immigrant entrepreneurs, little attention has been paid to how the significance of ethnic and class resources changes over the course of business development. Thus, I take into consideration not only how ethnic and class resources have been used in Korean immigrant businesses but also how the importance of those resources has varied with time. Reflecting on the relevant changes in business types, business scale, and use of ethnic and individual resources over the last 50 years, I have organized and classified my field data into three periods: (1) the 1960s and 1970s, when ethnic networks were crucial to the Korean entry into subcontracted knitting and sewing jobs; (2) the 1980s and 1990s, which saw a high reliance on ethnic resources during the expansion of Korean garment businesses into the commercial sector; and (3) the 2000s and 2010s, when class and individual resources became much more important for immigrants than ethnic resources. This periodization facilitates a thorough analysis of how and why the ethnic and class resources affecting the involvement of Korean Argentines in the garment industry have changed and evolved.

While ethnic resources are regarded as a vital advantage for immigrant businesses, some scholars also found negative effects of ethnic resources and business concentration in certain areas. Kim and Hurh (1985) claim that while such ethnic resources benefit the immigrants' business entry and give them a competitive advantage, the same mechanism poses serious problems: intra-ethnic business competition and a precarious position as a middleman minority. In a similar vein, Min (1990) examined major problems experienced by Korean immigrant entrepreneurs in the United States. As their businesses are concentrated in residential areas of lowincome minorities, Korean entrepreneurs are vulnerable to exploitation by out-group suppliers and landlords. In addition, Korean concentration in the ethnic economy hinders cultural and social integration into mainstream society. Thus, in this research I pay particular attention to those negative effects caused by high dependence on ethnic resources and intensive 
concentration of their businesses in a particular sector. Furthermore, I shed light on the negative effects of informal financial support, a topic that has not been studied in North America but that has critically influenced the transformation of Korean businesses in a typical developing country like Argentina.

\section{(1) The 1960s and 1970s: Ethnic Networks and Sewing and Knitting Jobs}

Koreans first began to arrive in Argentina in 1965 under a governmental program designed to boost the country's agricultural sector (Jeon, 1996:62). They were settled in the province of Rio Negro on previously unworked land, which they were expected to work (Jeon, 1996:62). However, as most of the immigrants' experience had been in office environments, they struggled with the work involved in establishing and running farms. The Korean government tried to support them, but their lack of experience in farming and in the agricultural industry and insufficient economic resources led to feelings of maladjustment, resentment, and unhappiness (Park, 2013). The agricultural projects' lack of success proved a crucial factor in the trajectory of Korean immigrants in Argentina, as their desperate circumstances compelled most of them to resettle in Buenos Aires (Lee, 1992:130-134). Irrespective of their former social and economic backgrounds, most Korean immigrants who resettled in poor neighborhoods of Buenos Aires began their new lives as unskilled workers, such as dishwashers, waiters, and street-corner greengrocers (Lee, 1992:130-134).

In Buenos Aires, sewing and knitting jobs were discovered by early Korean immigrants by mere chance, and gradually, most Koreans followed in their path, focusing their economic activities primarily on that industry, working as sub-contractors for Jewish factories in the city's slum areas (Kim, 2020). As many previous scholars in migration studies (Waldinger et al., 1990; Light and Bonacich, 1991; Light and Rosenstein, 1995; Barrett et al., 1996; Light and Gold, 2000) have found, newly arrived groups usually encounter a variety of difficulties in socially and economically integrating into their host countries. For example, finding employment in host contexts can be particularly challenging when immigrant groups are disadvantaged due to language barriers or ethnic/racial discrimination, among other factors. As most of my interviewees emphasized, the main driver of self-employment for the first generation of Koreans in Argentina 
was the language barrier, which closed doors to them in the labor market. For those in the early stages of immigration, the garment sewing and knitting subcontracted work was one of the most suitable options as it could be carried out without significant language skills or capital investment.

As new Korean migrants did not speak the local language and encountered difficulties in the host society due to the disadvantages they faced, reliance upon the Korean community was the natural and sometimes only path to earning a livelihood and building a life in Argentina. The community offered them resources they could draw on in their adaptation process, including access to business information, job opportunities, and training. For instance, more than one-third of the interviewees who immigrated in Argentina in the 1960s and 1970s stated that they started their garment business directly after immigrating to Argentina. In only two cases had Korean immigrants or their family operated garment businesses in Korea. From this information, I infer that Korean immigrants opted first for the garment business as a result of their intensive dependence upon community networks.

According to Lee (1992:87-89), a Korean female immigrant in Villa Rivadavia (Flores) with previous home-country experience in machine knitting found that immigrants like herself could earn money as machine knitters subcontracted by the earlier-established Jewish business community. This pioneering woman and her husband taught other immigrants how to operate knitting machines and distributed tasks among other immigrants (Lee, 1992:87-89). This community training was popular among female immigrants, since after only a week of practice, they could immediately start earning an income and thus help their families (Lee, 1992:87-89). Initially, female immigrants supplemented male immigrants' income through home-based machine knitting work (pyeonmul). Eventually however, male immigrants joined in managing the larger knitting machines (yokko) (Lee, 1992:187). Beginning in 1968, Korean immigrants also became involved in machine sewing (Lee, 1992:187). Unlike the noisy machine knitting that attracted complaints from neighbors, machine sewing was a quiet, more agreeable job to conduct in the family home. According to Lee (1992:241), while Korean immigrants concentrated on machine knitting work from 1967 to 1975, subcontracted sewing work became more popular after 1975 .

As mentioned above, in the early stage of Korean immigration in Argentina, co-ethnic solidarity facilitated an extensive reliance on community networks, which in turn aided in the efficient transmission 
of skills and the distribution of tasks, materials, and opportunities. The more experienced immigrants taught newer arrivals how to operate sewing and knitting machines (Lee, 1992:183). Some of the most experienced served as job distributors, basically as "middlemen" between the local manufacturers and other Korean subcontractors; they assigned tasks according to materials, models, and colors to improve worker efficiency. For their efforts, they received commissions from Korean subcontractors (Lee, 1992:181). Subcontracting was sometimes carried out among families and larger kinship groups, as well as in cooperation with the local extended Korean immigrant community. As the following interview suggests, Korean immigrants were highly dependent on ethnic networks in the early stage of their settlement in Buenos Aires:

\begin{abstract}
I came to Argentina in 1975 after my sister invited me to come. I spent $\$ 1,500$ [US] dollars on the flight, so I had only \$200 [US] dollars in hand. Imagine, around that time my mother-in-law's house in Seoul cost $\$ 1,500$ [US] dollars. We could not afford to buy a house here at all. It's the reason why we went to a poorer area. We first lived and worked in a [Korean] friend's house, where there were four sewing machines. There, I learned how to operate sewing machines and worked for several months. Then I set up an independent workshop with the help of a Jewish manufacturer. (Interview, February 24, 2014; male, 67 years old, migrated in 1975; author's translation)
\end{abstract}

Furthermore, in the Korean community in Argentina, ethnic churches seem to have been a key site for sharing information and opportunities. Studies conducted in the United States show that Korean ethnic organizations facilitated social interaction; these included churches, alumni, media, and social and recreational associations (Thomas and Ong, 2015). Religious institutions are of particular importance as approximately $80 \%$ of the Koreans in the United States are Christian (Min, 1992; Choi, 2010). Korean churches are places where new immigrants can meet and interact with other Koreans. In the Southern California region, approximately 800 Korean churches function fundamentally as ethnic networks (Min, 1992; Choi, 2010). Several interviewees mentioned that Korean churches helped them to meet other Koreans and to share business information, as in the interviews below:

We got the business information at church. [Korean] churches functioned largely as information centers for many Korean immigrants. Korean immigrants obtained the information at church. For example, that's where they learned where to buy or repair sewing machines and get work. (Interview, February 24, 2014, male, 67 years old, migrated in 1975; author's translation.) 
When we arrived, we got information from other Koreans. Everyone went to the Korean church for information. It was good to work with them [other Koreans] when you understood absolutely nothing about the host country. However, there was always a lot of competition among Koreans, like these days in the wholesale sector. They were not honest with all the information they gave out. For instance, they didn't tell us the real sewing prices per unit. (Interview, May 7, 2014; female, 55 years old, migrated in 1979; author's translation)

As many of my interviewees suggested, informal network ties within the ethnic community were an important factor that facilitated the entry of the new immigrants into sewing and knitting jobs. Initially, most Korean immigrants relied on the practical support and the companionship of acquaintances, close friends, and church members within their ethnic community, for a range of reasons including language, job opportunity, and lack of familiarity with the environment.

\section{(2) The 1980s and 1990s: Ethnic Resources and the Commercial Expansion of Korean Garment Businesses}

The knowledge and skills Korean immigrants gained in the menial sewing and knitting jobs they undertook in the 1960s and 1970s proved crucial to their long-term economic security, providing them with a solid foundation and market advantage as they began to open wholesale businesses and retail stores in the 1980s (Lee, 1992; Kim, 2020). The role of ethnic resources and networks within the Korean business community was particularly important in the process of moving toward the commercial garment sector. As the larger scale of business required greater capital, they were highly dependent on co-ethnic financial systems, specific industry information, and informal networks they had forged between co-ethnic manufacturers, wholesalers, and retailers. I analyze instances of such dependence thoroughly as well as point out the negative effects of this high dependence on ethnic resources.

\section{Korean Independent Manufacturers and the Booming of Korean Wholesale and Retail Garment Shops}

The comparative advantages and know-how Korean immigrants accumulated while working in the apparel sector in the previous decades fueled impressive growth in the wholesale and retail garment markets in the 1980s and 1990s. One of the driving forces was the informal Korean 
home-based factories which supplied ready-made apparel to co-ethnic wholesalers and retailers who were not involved in garment manufacturing themselves. The role of these independent manufacturers was extremely important in the overall development of the Korean apparel business in Argentina. They were engaged exclusively in garment production: designing, producing, and supplying apparel to Korean retailers or wholesalers. These home-based plants were neither formally operated nor open to non-Koreans. Only Korean immigrants knew about them, through the community networks, and they were a highly prized resource providing a comparative market advantage (Kim, 2020). The following interview comment attests to this:

\begin{abstract}
Those manufacturers allowed the retailers to bypass the wholesalers. At night, many Korean retailers visited our factory to buy stock, because if they avoided wholesalers, they got higher profit margins. Argentine retailers bought from Korean wholesalers in Once [neighborhood] during the daytime. I mean Argentine retailers had to go through one more step and got smaller margins. (Interview, May 14, 2014, male, 47 years old, migrated in 1976; author's translation.)
\end{abstract}

For Korean wholesalers who did not have the experience and knowledge to manufacture apparel themselves, these suppliers were crucial, because these informal factories allowed them simply to buy ready-made stock and resell it to local retailers. Korean retailers in the provinces also bought stock directly from these co-ethnic manufacturers, thus bypassing wholesalers, in this way obtaining it at wholesale prices and selling it at a higher profit margin. This cooperation helped new Korean entrepreneurs to compete with established Argentine wholesalers and retailers.

The growth of Korean garment manufacturing coincided with the opening of Korean retail shops in Argentina's provinces, beyond the City of Buenos Aires. According to Lee (1992:248-249) and my interviewees, there were many advantages to operating retail garment shops in the provinces. An obvious advantage was that the shop rent was much cheaper; further, property owners did not require that Korean retailers sign a lease guarantee bond such as that imposed by the City of Buenos Aires. Moreover, they were able to purchase stock on credit or with post-dated cheques from Korean wholesalers or manufacturers, based on ethnic networks and trust.

Table 1 indicates that the number of Korean-owned wholesale shops in the Buenos Aires capital district and retail shops in the provinces increased sharply in the 1980s. That growth was buoyed by a credit system 
Table 1. Numbers of Korean Garment Shops in Argentina (Lee, 1992:318, 327)

\begin{tabular}{lrrr}
\hline Year & 1986 & 1988 & 1990 \\
\hline Korean wholesale shops in Once neighborhood & 139 & 117 & 245 \\
Korean wholesale shops around Avellaneda Aver & 4 & 42 & 85 \\
Korean retail shops in the provinces & 96 & 132 & 204 \\
\hline
\end{tabular}

based on ethnic bonds among Korean retailers, wholesalers, and manufacturers (Lee, 1992:249).

As examined previously, ethnic networks were crucial in enabling Korean immigrants to start up their own enterprises via subcontracted garment sewing and knitting jobs. Similarly, those networks also facilitated their entry into the garment industry in later periods; this included those immigrants who came to Argentina under the investment category in the 1980s and 1990s as, is evident in the following comment:

\footnotetext{
We immigrated here in 1993 under the investment category. I took over a retail shop in the city of Buenos Aires from an earlier Korean immigrant. He taught me where the manufacturing plants were and which items I could get from each factory. At that time we shared information in this way. Reliance on the community was indispensable. (Interview, June 4, 2014, female, 54 years old, migrated in 1993; author's translation.)
}

The above interview suggests that newcomers highly depended on the community networks irrespective of the time period; this was primarily driven by the language barrier that most Korean immigrants encountered on arrival in Argentina. However, ethnic networks were helpful not only for new immigrants but also for those well settled, especially when they decided to change businesses. An interviewee who entered the garment industry after working in another sector made an interesting comment regarding this assistance from the Korean community:

I studied accounting at [the] University of Buenos Aires. After I graduated from the university, I got married and continued my family's business, lighting store. My husband ran commercial businesses. Because of the bad economic situation in the 1990s, he quit and we started a retail clothing shop on Cabildo [Ave.] in the district of Belgrano, a wealthy neighborhood in Buenos Aires. We would buy high-quality clothing from Korean wholesale shops on Avellaneda [Ave.] or from [direct] manufacturers. At that time, there were many Korean factories. We got the information from friends: where those factories were situated and which shops in Avellaneda [Ave.] had good quality clothes, neat sewing or stylish 
garments. Actually, going with businesses that other people had been running was much easier than finding new ones in other areas. Following what the others have been doing is much easier. Because more than $90 \%$ of Koreans are running garment businesses, this is the easiest thing to do. It is much easier than finding a new area, because there are friends and family who can help. (Interview, April 23, 2014, female, 50 years old, migrated in 1970; author's translation.)

As demonstrated in the above interview, mutual aid in the form of business opportunities and information provided Korean immigrants with a strong base on which they could initiate and develop their own businesses. Yet, unfortunately, the combined effect of this high dependence on ethnic ties as well as cutthroat price competition between Korean retailers within the same cities had unwanted negative consequences. Price wars were a huge problem for retailers in the provinces, because they ran the same type of business and sold the same or similar types of clothing made by the same Korean manufacturers, as the below interview suggests:

There has been always too much competition between Koreans. Twenty years ago when I ran a retail shop in Morón, there were three other Korean shops on the same block, plus another three on the next block. Korean retailers always checked the windows of other Korean retail shops and then adjusted their prices. When I visited Korean factories, I had to grab hot items before other retailers, because they were gone too fast. (Interview, June 4, 2014, female, 54 years old, migrated in 1993; author's translation.)

Among Korean retailers in the same city, price fixing was proposed as a solution in order to maintain profits and avoid competing with one other. However, cartelization was not easy to achieve because some who wanted free competition did not agree to fixing the price; in addition, "dishonest" retailers did not respect the agreed prices, as the following experiences and views show:

I don't know how it works now, but when I ran a business in La Plata [in the late 1990s], competition was high. There were 12 Korean retailers there. They [the other Korean retailers] asked us to agree to a fixed price guide there. We got together every month and reviewed the guide: for example, remera [t-shirt] prices were fixed at $\$ 10$ pesos, blusa [blouse] at $\$ 15$ pesos. From time to time, they also checked the prices, so that everyone would respect them. However, there were some bad and dishonest people who didn't. (Interview, February 28, 2014, female, 57 years old, migrated in 1994; author's translation.)

Similar stories were presented by many Korean interviewees. Intra-ethnic business competition is not unique to Argentina; for example, it has also 
been observed among Korean businesses in the United States. Kim and Hurh (1985) argued that while ethnic resources can facilitate business entry and provide competitive advantages, they may cause serious problems, including intra-ethnic business competition. They explain this competition in terms of the "overcrowded effect" (Kim and Hurh, 1985:105). In the absence of attractive alternative employment opportunities in the host country, a disproportionate number of Korean immigrants tend to enter the same types of markets and engage in the same types of businesses, utilizing the same ethnic resources and networks (Kim and Hurh, 1985:105). As a result, such hyper-concentration in a specific business area intensifies intra-ethnic business competition, as with the overabundance of Korean retail garment shops within the same provincial Argentine cities.

\section{Co-Ethnic Financial Support}

Some scholars of immigrant entrepreneurial studies (Light and Bonacich, 1991; Light and Gold, 2000) have argued that an ethnic group's internal organizational capacity and its strength determine the limits of exploitation opportunities. Ethnic groups with a high level of organization provide coethnics with a collective capacity for organizing new ventures. Although the main source of the initial capital for most small businesses is the owner's savings, in many cases, other sources of funds are sought (Light and Gold, 2000:114-115). Light and Gold (2000:114-115) suggested that co-ethnic support in terms of financing plays a particularly vital role for immigrant entrepreneurs, because such funding was the most important source of accessible financial capital beyond personal savings. For example, in his study, Yoon (1997:142) demonstrated that Korean entrepreneurs in Chicago depended on several co-ethnic loan sources to initiate their businesses: $35 \%$ from kin, $19.9 \%$ from friends, $13.7 \%$ from Korean American banks, and $27.9 \%$ from gye funds (Korean rotating credit system). Furthermore, the valuable and helpful functions of the gye system have been analyzed by various scholars who have studied Korean immigrant business in the United States (Light and Bonacich, 1991:247255; Yoon, 1997:141-146; Light and Gold, 2000:114-115).

My field data indicate that sharing financial resources among co-ethnic members was a direct and powerful tool in raising the initial funds for Korean entrepreneurs in Argentina. As the scale of Korean businesses expanded, larger amounts of capital were required. In the early years, Korean entrepreneurs in Argentina often effectively used gye (or kye), their 
informal Korean rotating saving and credit system. This trust-based system was important for raising capital to rent the shops, upgrade machinery, and much else. Many of my interviewees mentioned that they made use of the gye system at the beginning of their business operation; they viewed it as one of the most important factors in the growth of Korean immigrant businesses.

Nevertheless, countless negative effects of the gye system were also presented in my interviews and conversations with Korean entrepreneurs. As this system is totally informally operated, it is completely dependent upon the reliability of the members. If someone did not repay the money, it was difficult to maintain the system, as the story below demonstrates:

\begin{abstract}
When I opened this store, I got the money from four different gyes of \$2,000 [US] dollars each. After getting gye money in the first turn, I rented this shop. Of course, I did not have money for the stock, so I took out credit from Korean wholesale shops and factories to buy it. I paid them back on time and kept up my credit with them. I also paid the gye money back every month. Without those gye funds and credits from Korean wholesale shops, I wouldn't have been able to open my own [retail] shops. Afterwards, I did gye several times and lent money to my son's friend's mom to help them, but unfortunately in the end, many did not pay me back. After those experiences, I don't lend money to Koreans or do gyes anymore. I lost not only the money but also the people. (Interview, May 2, 2014, female, 55 years old, migrated in 1984; author's translation.)
\end{abstract}

The problems and conflicts among Korean immigrants in Argentina resulting from abuses of gye and other personal loans were exacerbated by the high inflation rate and the frequent cyclical economic crises in the host country (Kim, 2020). In such a context, it was difficult to keep the rotating saving and credit system afloat, because the real value of the funds wildly fluctuated, almost daily, during the phases of the rotation.

Other credit systems between wholesalers and retailers or between manufacturers and wholesalers/retailers were also helpful in the development of Korean businesses. By depending on ethnic networks, Korean entrepreneurs established reliable relationships using credit or post-dated cheques. However, such high dependence had some negative consequences, because of the many entrepreneurs who exploited the difficult economic circumstances in the host country to take advantage of others. This interviewee illustrates this abuse:

In those days we used 90 - or 150-day post-dated cheques. The problem was the high rate of inflation. You never knew the actual [US] dollar exchange rate or the real value of money. People made improper use of this situation and dishonored 


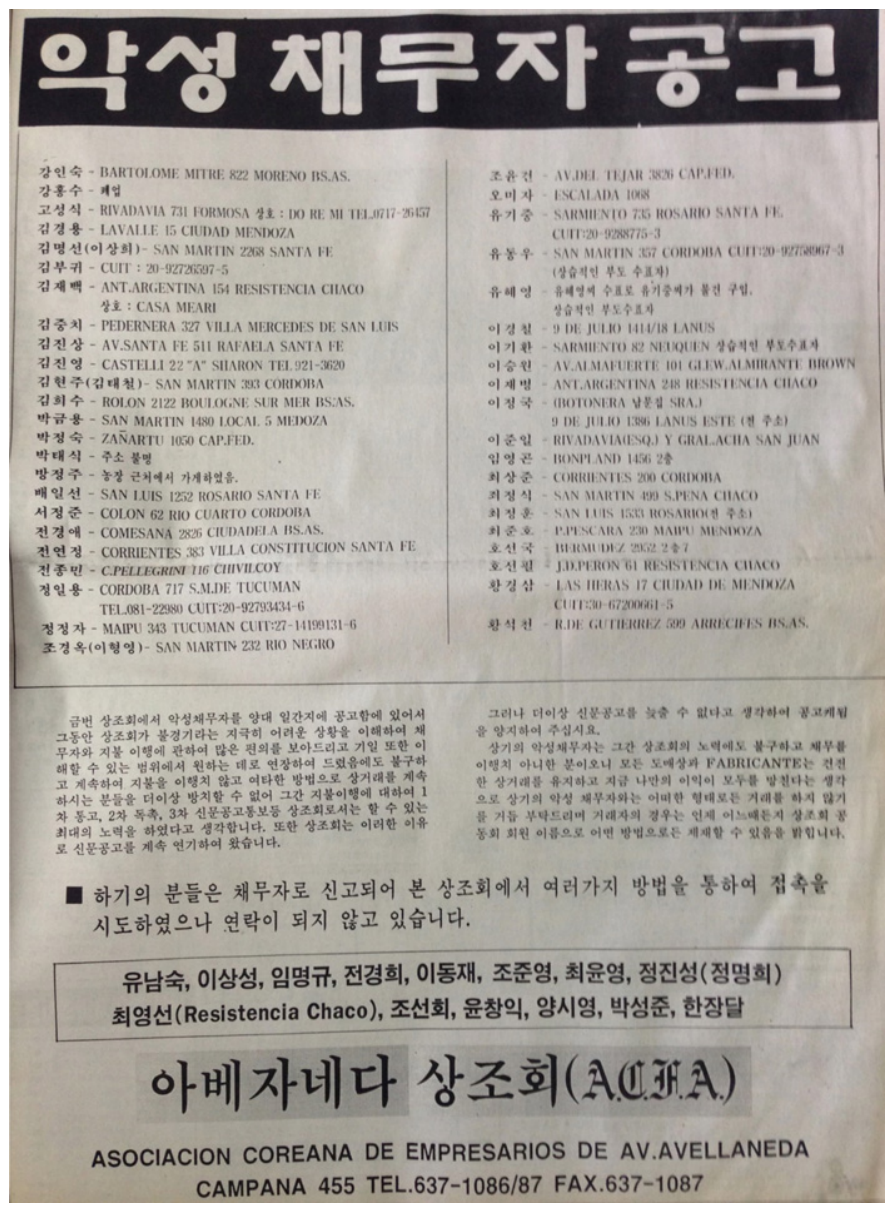

Fig. 1. The list of problematic debtors according to the Korean Association of Avellaneda Ave. Entrepreneurs (former Chamber of the Korean Entrepreneurs in Argentina) in The Korea Times Buenos Aires on the $7^{\text {th }}$ of December, 1995.

the cheques intentionally. Most people who did this were Koreans, although there were some Argentines as well. They had the capacity to return the money on time but extended the period to make a further profit from inflation. (Interview, May 11, 2014, male, 65 years old, migrated in 1967; author's translation.)

The majority of those I interviewed mentioned, without prompting, negative experiences relating to credit and money issues with co-ethnic Korean entrepreneurs. It was clear that ethnic networks helped Korean immigrants in their business ventures in many respects. However, not all 
Korean entrepreneurs adhered to the moral values held by their predecessors; thus, in some cases, increasing reliance on ethnic networks yielded negative effects.

The issue of problematic debtors not repaying borrowed funds came to a head in the 1990 s, by which time it was posing a serious challenge to the Korean business community. Eventually, it became the primary motive for the establishment of the Korean Association of Avellaneda Ave. Entrepreneurs (now the Chamber of the Korean Entrepreneurs in Argentina) in order to deal with the problem collectively. One of the association's first actions was to publish a list of problematic debtors-in a name-and-shame exercise-in the community newspapers as a means of damage control (Fig. 1).

\section{(3) Ethnic Resources Today: "It's Not an Ethnic but an Individual Business"}

In the new century, the scale, types, and management styles of Korean immigrant businesses have again significantly changed. In the 1980s and 1990s, while the entire industry - both production and retail or wholesale distribution-was dominated by Koreans, individual entrepreneurs specialized in one or the other. In the 2000s, when manufacturers began to open outlets in the Avellaneda Ave. wholesale district, existing wholesalers responded by expanding into production. As a result, many Korean businesses now have both production and wholesale arms. Some also run mid-sized wholesale operations or small retail outlets with stock obtained from wholesalers (Kim, 2020).

Today, co-ethnic resources are no longer the dominant element of the immigrant experience, with immigrant entrepreneurs no longer drawn into the garment business due to co-ethnic influence or capital. For instance, the use of gye in the Korean community, as noted previously, has gone into sharp decline due to numerous problems related to unpaid debts. Many interviewees professed to having set up their businesses with their own savings, without any reliance on loans or credit. While gye was still used for business purposes in limited cases, mostly it is now employed for nurturing friendships. In any case, as Korean immigration to Argentina almost completely dried up in the new century, there are very few new immigrants looking for work or wanting to start a business. Still, even though the ethnic community is no longer the primary source of direct business information or capital, Koreans are still likely to get general information from 
community newspapers or websites run by the Korean Association or the Korean Chamber of Commerce, for example Koreans selling their businesses to other Koreans. They also tend to obtain specific businessrelated information from close friends or members of their own church.

Furthermore, contrary to my expectation, several Korean interviewees asserted: "I started and developed my business without any help from the other community members" or "It's not an ethnic but an individual business." This kind of comment was more common among current business operators than among those who managed a business in the earlier stage and did not have any choice but to depend on the ethnic network. Certainly, claims of total independence from ethnic resources are more prevalent among non-Korean entrepreneurs in the same sector; it is particularly true of Argentine entrepreneurs. Thus, I argue that ethnic resources should not be considered as an absolute condition for the establishment and development of Korean garment businesses but as one of the available resources facilitating the process, in most cases. In addition, contrary to the popular view that ethnic resources and networks have exclusively advantageous and positive effects, most of the Korean entrepreneurs I interviewed stressed negative aspects of "ethnic businesses." As previously analyzed in the case of Korean retailers, Korean wholesalers around Avellaneda Ave. also resent the fierce competition among co-ethnic entrepreneurs in the same sectors, as the comment below indicates:

The bad thing is that friends and relatives have become competitors in the end, because it is inevitable. We are running the same businesses in the same places. It's a pity, but this is how it is. (Interview, May 27, 2014, male, 45 years old, migrated in 1985; author's translation.)

The Argentine garment market is roughly composed of four market segments: (1) the first-line brands, which have their own local marketing and are sold in large shopping centers in many cases; (2) medium-sized companies, which do not usually have their own brands but reach end consumers through multi-brand shops; (3) semi-formal wholesale markets geographically concentrated in Once and Flores (around Avellaneda Ave.), which provide mid-quality apparel to registered retail shops; and (4) La Salada market, which provides clothing to small- and medium-sized retail businesses mostly operating as stalls in unregistered markets (Kim, 2020). While in the past Korean immigrants expanded rapidly into new industry sectors, in recent years they have been concentrating on the semi-formal 
market sector. In particular, Korean entrepreneurs dominate the midquality women's fashion within the wholesale market around Avellaneda Ave., alongside Jewish and Bolivian entrepreneurs who dominate the men's and children's apparel markets, respectively. As a result, there is more severe competition in the semi-formal wholesale markets, as compared to previous decades, as the comments below show:

The [garment] market is limited, so even if the Avellaneda Ave. [wholesale area] has been growing fast, there is too much competition among Koreans. Koreans could find other market segments instead of women's clothing just as highfashion apparel Jewish entrepreneurs on Helguera Street did. Jews sell them at high prices to clients different from ours. But all the Koreans are concentrated in the same segment, so they don't share business information and they compete with each other. (Interview, A pril 23, 2014, female, 50 years old, migrated in 1970; author's translation.)

While a considerable number of Koreans have achieved upward mobility, of course this does not apply to everyone. Certainly, there are some who remain fixed in the same place and some who have even experienced downward mobility. Several interviewees raised the issue of the gap between rich and poor, as in the interview below:

My parents came to Argentina with 20 dollars. We lived in a basement without hot water in a slum, but eventually they built a successful life. [ . . . In the beginning, it seemed that everyone helped everyone and Koreans got along together very well. However, it is impossible these days. Everyone competes against everyone. Koreans fight one another. I think the other problem is that the gap between rich and poor is getting wider within the Korean community. In the 1970s and 1980s, most immigrants were poor; [I mean] most were in a similar social class, but as time passes, 20 or 30 years on, the gap between rich and poor is getting huge. Those [Koreans] who own buildings around Avellaneda Ave. make millions and millions of dollars each month and accumulate more and more capital, but many more poor Koreans also appear each month. In the Korean churches, those [Koreans] who have more money tend to occupy the important positions. The gap between rich and poor also has caused many conflicts and problems in several churches. (Interview with participant whose information has been withheld, May 23, 2014; author's translation.)

As the above interview clearly demonstrates, the legendary upward mobility does not apply to all community members. As a result of these uneven trajectories, the cleavage between rich and poor grows deeper and wider within the Korean Argentine community, as it did for Argentines as a whole after several severe economic crises. In other words, although most 
of them are physically confined in a specific geographic location and industry sector, Korean entrepreneurs cannot be viewed as a unitary business group: huge differences emerge among community members in terms of economic position, background, life trajectory, and degree of integration into the host society. As the classical theorists of "ethnic and class resources" (Yoon, 1991; Light and Gold, 2000) claimed, while in the initial stage of Korean immigration and involvement in the garment industry ethnic resources played an essential role, today "class" resources appear to have become more significant for Korean businesses.

More to the point, the importance of "class" resources for current Korean businesses comes through in the analysis of young Korean entrepreneurs. Unlike second-generation Koreans in other countries, who tend to reject the small-business preferences of their parents and seek to pursue professional careers, Korean Argentines continue to choose work within the garment industry (Kim and Koo, 2017). While for young Korean Argentines the typical job market circumstances of a developing country, such as low salary, unemployment, underemployment, job dissatisfaction, and blocked opportunities, seem to have acted as push factors toward family business or co-ethnic job opportunities, my interviewees further claim that young Korean Argentines are in a position of advantage: the financial support and expertise offered by their families help them to better develop their businesses, as the following example demonstrates:

\begin{abstract}
I accumulated some savings while working with my mom, but it was not enough to start up a wholesale business. She helped me with the money to rent a shop and offered to share her cutting factory and storage space. She also contacted some fabric providers and asked them to provide me with fabric on credit. Without her help, it would have been completely impossible. She continues to help me today. (Interview, May 4, 2014, male, 30 years old, born in Argentina; author's translation.)
\end{abstract}

While first-generation Korean immigrants tended to depend on the wider ethnic community for seed capital and business information, my interviews and conversations with young 1.5- and second-generation Korean Argentines suggest that their main source of these forms of support is now their own families, including taking over the family firm (Kim and Koo, 2017). However, those who do not benefit from such family support can still turn to the wider Korean network, as this interview shows: 
My mother has been very successful in running retail garment shops in suburban Buenos Aires. I graduated from high school and university in the US. [ . . . ] When I came back, I wanted to run a retail shop because I know a lot about how to do that. However, my parents strongly suggested that I work at their friends' wholesale shop and learn how to manage wholesale. I worked there without pay just to learn the business. After a month a [wholesale] shop came on the market, so I bought it and started my own business. (Interview, May 14, 2014, female, 34 years old, migrated in 1984; author's translation.)

While there were a few cases of young Korean Argentines accepting a small amount of credit from friends or others, usually community members, I did not encounter any cases where they had started wholesale or retail clothing businesses exclusively on credit. Thus, unlike the first generation of Korean immigrants in Argentina, for the second-generation class resources are viewed as primary while ethnic resources constitute a secondary form of support.

\section{Conclusion}

Ethnic networks and resources were comparatively distinctive and accessible instruments that Korean immigrants could use in Argentina to bolster their entrepreneurial business activities and achieve upward social mobility. Nevertheless, the relative importance and dependence on those resources by Korean entrepreneurs vary with time period and circumstance.

In the 1960s and 1970s, Korean immigrants neither spoke the local language (Spanish) nor understood the local Argentine context. Most depended heavily on previous arrivals to resolve basic matters, from renting houses to seeking medical attention, as well as to find jobs and business opportunities. This is probably the main reason why in the early settlement stages Korean immigrants were concentrated in limited business areas, such as grocery shops or subcontracted garment sewing and knitting workshops, which were easy to manage following the information and advice provided by other Korean immigrants. Although the number of new arrivals declined after 2000, their reliance upon the ethnic community remained the natural or necessary path to earn a livelihood and to build a life in Argentina.

Furthermore, I found that many Korean immigrants relied on ethnic networks and resources not only in the early stages but also in the following phases, when they expanded their businesses into the retail and wholesale 
garment sectors. The informal Korean factories which supplied readymade apparel to co-ethnic wholesalers and retailers played a crucial role in this development. These co-ethnic factories were particularly important for those Korean retailers or wholesalers who did not have the know-how to engage in garment manufacturing themselves, as many interviewees confirmed. The informal Korean rotating saving and credit system of gye, post-dated cheques, and other types of credit were frequently used by coethnics. For many of the Koreans I interviewed, those informal financial systems based on co-ethnic networks were considered among the most important and direct aids in their expansion into the commercial garment sector. Direct motivation and encouragement from close friends or family were particularly influential in entrepreneurial decision-making, in terms of sharing core business information and raising start-up capital.

Nevertheless, ethnic resources based on informal community networks, which were previously viewed as an advantage available only to Korean entrepreneurs, also had unwanted side effects on the development of Korean garment businesses, some of which were articulated during my interviews and conversations with Korean entrepreneurs. Moreover, the difficult economic circumstances in the host country, such as cyclical crises of recession and high inflation, aggravated the financial problems and conflicts generated by the informal credit systems. Consequently, after countless problems related to unpaid debts among community members, participation in gye financial cooperatives decreased noticeably. Plus, with the substantial growth in the scale of Korean businesses, it became harder to rely on co-ethnic financial help to obtain the necessary resources.

Currently, ethnic resources and networks within the Korean business community pale in importance compared to previous decades. While ethnic networks are typically used, their role is considerably more limited to smaller-scale credit or information services provided by Korean associations and organizations. Meanwhile, Korean immigrants became "Argentine-ized" entrepreneurs in their own way, less dependent on ethnic resources and more focused on individual profits. Fierce competition among co-ethnics has become a serious issue, particularly in the wholesale garment sector; indeed, today, most Koreans carry out their businesses independently and are reluctant to divulge their business strategies and core information.

At first glance, from the standpoint of Argentine society, the Korean community was often seen as a unitary business group, because of its concentration in the physically bounded Avellaneda Ave. wholesale 
clothing district. However, upon closer observation, huge differences emerge among community members in terms of economic position, background, life trajectory, and degree of integration into the host society. Clearly, success story of upward mobility does not apply to all community members. Many Koreans remained locked in unsuccessful situations, unable to move upwards, and some have even experienced downward mobility. As a result of these uneven trajectories, the gap between rich and poor became wide within the Korean community.

As the classical theories of "ethnic and class resources" claimed, in the initial stage of Korean immigration and their involvement in the garment industry, ethnic resources played an essential role. Currently, however, "class" resources appear to have become more important for Korean businesses. This seems more evident in the case of young Korean Argentine entrepreneurs. Younger Korean Argentines with adequate capital can take over their parents' business and follow in their footsteps, whereas those who cannot get economic support from the family tend to work for other Korean entrepreneurs as employees. Currently, business opportunities seem restricted to those who have economic power, strengthening a phenomenon of intergenerational transmission of "class" or socioeconomic status (Bowles and Gintis, 2002; Solon, 2002).

Although they are significantly concentrated in a specific industry, in fact, Korean entrepreneurs operate their individual businesses. In other words, they are currently running individual businesses under the label of "ethnic business," a label that simply reflects the high concentration of Koreans in the garment industry. In the final analysis, it is clear that the accumulated know-how and economic power of each individual Korean entrepreneur leads to a certain path-dependency, motivating the community members to continue to benefit from the advantages whenever possible; nevertheless, "ethnicity" or "ethnic networks/ resources" is not an absolute condition of or key to explaining the high concentration of Korean ethnic businesses in the Argentine garment industry.

As a unique case study on Korean immigrant entrepreneurs in Latin America, where the history, settlement, and current status of immigrants have been relatively underexamined in comparison with their North American counterparts, this study provides an in-depth analysis of the transformation of Korean immigrant entrepreneurship in Argentina with a particular focus on ethnic and other available resources. While identifying the particular issues that have arisen in Korean ethnic businesses in one of 
Latin America's core countries, this study makes a significant contribution towards bridging the gap between research on the North and the South and advances future comparative research in the field of Korean migration studies.

\section{Acknowledgments}

I am very grateful to the editors of the Journal (Prof Christopher Bae and Dr Harrison Kim) and the two anonymous reviewers for their time and valuable comments. My special thanks go to Dr Sunhee Koo, without whose support this research and publication project would not have been possible. I would also like to express my gratitude to Wally Kairuz and Mona-Lynn Courteau, who helped revise and improve this article. I also appreciate the support provided for this publication by the Research Centre for Migration, Diaspora and Exile at the University of Central Lancashire.

\section{References Cited}

Barrett, G., Jones, T., McEvoy, D., 1996. Ethnic minority business: Theoretical discourse in Britain and North America. Urban Studies 33(4-5), 783-809.

Bonacich, E., 1973. A theory of middleman minorities. American Sociological Review 38(5), 583-594.

Bowles, S., Gintis, H., 2002. The inheritance of inequality. The Journal of Economic Perspectives 16(3), 3-30.

Choi, H., 2010. Religious institutions and ethnic entrepreneurship: The Korean ethnic church as a small business incubator. Economic Development Quarterly 24(4), 372-383.

Collins, J., 2008. Immigrant entrepreneurs in Australia: Regulations and responses. Migracoes: Journal of the Portugal Immigration Observatory 3, 49-60.

Jeon, G.S., 1996. Segyeui Hanminjok (6): Jungnammi [Koreans in the world (6): Latin America]. Seoul: Tongirwon.

Kim, K.C., Hurh, W.M., 1985. Ethnic resources utilization of Korean immigrant entrepreneurs in the Chicago minority area. The International Migration Review 19(1), 82-111. 
Kim, J., Koo, S., 2017. From father to son: 1.5- and second-generation Korean Argentines and ethnic entrepreneurship in the Argentine garment industry. The Review of Korean Studies 20(2), 175-201.

Kim, J., 2020. Ethnicity, opportunity, and upward mobility: Korean entrepreneurship in the Argentine garment industry 1965-2015. Asian Ethnicity 21(3), 373-392.

Kloosterman, R., 2010. Matching opportunities with resources: A framework for analysing (migrant) entrepreneurship from a mixed embeddedness perspective. Entrepreneurship and Regional Development 22(1), 25-45.

Kloosterman, R., Van Der Leun, J., Rath, J., 1999. Mixed embeddedness: (In)formal economic activities and immigrant businesses in the Netherlands. International Journal of Urban and Regional Research 23(2), 252-266.

Kloosterman, R., Rath, J., 2001. Immigrant entrepreneurs in advanced economies: Mixed embeddedness further explored. Journal of Ethnic and Migration Studies 27(2), 189-202.

Lee, G.B., 1992. Areuhentina haninimin 25nyeonsa [History of 25 years of Korean immigration in Argentina]. Busan: Seonyeongsa.

Light, I., 1984. Immigrant and ethnic enterprise in North America. Ethnic and Racial Studies 7(2), 195-216.

Light, I., Bonacich, E., 1991. Immigrant Entrepreneurs: Koreans in Los Angeles, 1965-1982. Berkeley: University of California Press.

Light, I., Rosenstein, C., 1995. Race, Ethnicity, and Entrepreneurship in Urban America. New York: Aldine Transactions.

Light, I., Gold, S., 2000. Ethnic Economies. San Diego: Academic Press.

Min, P.G., 1990. Problems of Korean immigrant entrepreneurs. International Migration Review 24(3), 436-455.

Min, P.G., 1992. The structure and social functions of Korean immigrant churches in the United States. International Migration Review 26(4), 1370-1394.

Min, P.G., 1996. Caught in the Middle: Korean Merchants in America's Multiethnic Cities. Berkeley: University of California Press.

Min, P.G., Kolodny, A., 1999. The middleman minority characteristics of Korean immigrants in the United States. In: Kim, K.C. (ed.), Koreans in the Hood: Conflict with African Americans. Baltimore: Johns Hopkins University Press, pp. 131-155.

Park, H.J., 2013. Nobody Remembers the Losers: The Story of Korean Agricultural Emigration to South America. Ph.D. Dissertation, The Australian National University. 
Portes, A., 1987. The social origins of the Cuban enclave economy of Miami. Sociological Perspectives 30(4), 340-372.

Portes, A., Shafer, S., 2007. Revisiting the enclave hypothesis: Miami twenty-five years later. Research in the Sociology of Organizations 25, 157-190.

Rath, J., 2002. Unravelling the Rag Trade: Immigrant Entrepreneurship in Seven World Cities. Oxford: Berg Publishers.

Solon, G., 2002. Cross-country differences in intergenerational earnings mobility. Journal of Economic Perspectives 16(3), 59-66.

Thomas, W.F., Ong, P.M., 2015. Ethnic mobilization among Korean dry-cleaners. Ethnic and Racial Studies 38(12), 2108-2122.

Turner, J., Bonacich, E., 1980. Toward a composite theory of middleman minorities. Ethnicity 7, 144-158.

Waldinger, R., 1986. Through the Eye of the Needle: Immigrants and Enterprise in New York's Garment Trades. New York: New York University Press.

Waldinger, R., 1989. Structural opportunity or ethnic advantage? Immigrant business development in New York. International Migration Review 23(1), 48-72.

Waldinger, R., Howard, A., Robin, W., 1990. Ethnic Entrepreneurs: Immigrant Business in Industrial Societies. Newbury Park, CA: Sage Publications.

Yoon, I.J., 1991. The changing significance of ethnic and class resources in immigrant business: The case of Korean immigrant business in Chicago. International Migration Review 25(2), 303-332.

Yoon, I.J., 1997. On My Own: Korean Businesses and Race Relations in America. Chicago: University of Chicago Press.

Zenner, W., 1991. Minorities in the Middle: A Cross-Cultural Analysis. New York: SUNY Press.

Zhou, M., 1995. Chinatown: The Socioeconomic Potential of an Urban Enclave. Philadelphia: Temple University Press.

Zhou, M., 2009. Contemporary Chinese America: Immigration, Ethnicity, and Community Transformation. Philadelphia: Temple University Press. 